\title{
VALIDATION OF A TECHNOLOGICAL PEDAGOGICAL CONTENT KNOWLEDGE INSTRUMENT IN A MALAYSIAN SECONDARY SCHOOL CONTEXT
}

\author{
Hasniza Nordin \& Tengku Faekah Tengku Ariffin \\ School of Education \& Modern Languages \\ Universiti Utara Malaysia
}

Corresponding author: nizadin@uum.edu.my

\begin{abstract}
Purpose - This study focused on the validation of a Technological Pedagogical Content Knowledge (TPACK) instrument for using ICT in teaching and learning effectively in a Malaysian secondary school setting. The aim of this study was to confirm a sevenfactor TPACK model which includes Technological Knowledge, Content Knowledge, Pedagogical Knowledge, Pedagogical Content Knowledge, Technological Pedagogical Knowledge, Technological Content Knowledge and Technological Pedagogical Content Knowledge.
\end{abstract}

Methodology - This study was designed as a case study situated within a particular context in Malaysia. A survey was administered to 150 pre-service teachers enrolled in a university in Malaysia. Confirmatory factor analysis (CFA) of the adapted TPACK survey was preceded by assessing the fit of the measurement model with the data in the study based on the a priori theoretical model.

Findings - The findings revealed that the measurement model adequately fit with the data collected within a Malaysian secondary school context, also lending validity to the adapted TPACK instrument used in this study.

Significance - The adapted and translated TPACK survey was found to be a valuable self-report instrument for measuring pre-service teachers' TPACK knowledge. A greater understanding of TPACK may be required for pre-service teachers before adequate gains in using ICT in teaching can be achieved. Thus, it is recommended that this knowledge should be integrated in the Initial Teacher Education curriculum with more attention to improving access to ICT in Initial Teacher Education and the schools. 
Keywords: pre-service teachers; TPACK; field experience; instrument validation; school

\section{INTRODUCTION}

Promoting the development of quality teachers is important in enhancing the quality of education (Harris \& Sass, 2011). However, most countries, both developed and developing, are facing the challenging issue of producing quality teachers in the 21 st century (Townsend \& Bates, 2007; Timperley, 2012). In January 1997, the Ministry of Education conceptualised the vision of the Malaysian Smart School and the Ministry was made responsible for managing its "Smart School Flagship" (Ministry of Education Malaysia, 1998). About 8,000 schools were equipped with computer facilities under the Smart School project. Malaysia's "Vision 2020" aims to become a "fully-developed nation by 2020 " (Frost \& Sullivan, 2010, p. 14). In December 2011, Internet-enabled education was to be realized under the new phase of education transformation by the implementation of 1 BestariNet project. It is expected that 10,000 primary and secondary schools across the country are to be equipped with high-speed $4 \mathrm{G}$ mobile Internet in an integrated platform, a Virtual Learning Environment (VLE), known as Frog VLE (Ministry of Education Malaysia, 2012). It was reported in the Malaysian Education Blueprint (2013-2025) that RM6 billion was allocated for ICT in teaching and learning (Ministry of Education, 2012).

With the advent of ICT, learning becomes interesting and allows learners, for example, to learn language using computer games in acquiring vocabulary (Young \& Wang, 2014) and utilize mobile learning for distance learners (Zaibon \& Shiratuddin, 2010). However, teachers' ability to use the provided tools is highly critical in realizing the benefits of ICT (Al-Ruz \& Khasawneh, 2011). According to Davis (1992), Information Communication Technology (ICT) in the field of initial teacher education has become an important issue since it was first introduced in the UK about 1980s. However, developing pre-service teachers' skills to incorporate ICT into their teaching effectively remains a concern for initial teacher education (Law, 2010; Kirschner \& Davis, 2003; UNESCO Bangkok, 2013). Research indicates that effective integration of ICT in teaching and learning requires the teacher to understand how ICT weaves with 
pedagogy and content, better known as Technological Pedagogical Content Knowledge (TPACK) (Mishra \& Koehler, 2006; Schmidt, et. al., 2009; Archambault \& Crippen, 2009; Lux, Bangert \& Whittier, 2011).

Pre-service teachers are being prepared to develop throughout their career in terms of improving their teaching methods, to learn more about the use of ICT, to increase their knowledge of certain subject matter, and to know how their students think and learn (Alayyar, Fisser, \& Voogt, 2012). Therefore, it may be valuable to understand pre-service teachers' TPACK as a way to estimate how well they are prepared to effectively integrate ICT in their teaching. As a standard practice, pre-service teachers should first be able to understand the relationships between "technological knowledge", "pedagogical knowledge", and "content knowledge" before they can become creative in the use of ICT in schools (Mishra \& Koehler, 2006). This explains why the TPACK framework has been considered as a useful tool for understanding how pre-service teachers can integrate technology into teaching and learning (Baran, Chuang, $\&$ Thompson, 2011). Thus, using TPACK is one of the strategic ways to evaluate or assess pre-service teachers' skills in integrating the use of technology in teaching (Schmidt et al., 2009; Sahin, 2011; Lux, Bangert \& Whittier, 2011). In line with this, several studies have acknowledged the need to develop a more reliable and valid instrument when measuring pre-service teachers' TPACK (Mishra \& Koehler, 2006; Schmidt et. al., 2009; Archambault \& Crippen, 2009). Several TPACK surveys that were developed and tested on teachers in the United States were reported to be of high internal reliability (Schmidt et al. 2009; Archambault \& Crippen, 2009). Likewise, several studies attempted to validate the TPACK instrument in different contexts of study (Jang \& Tsai, 2012; Sahin, 2011; Lee \& Tsai, 2010; Koh, Chai \& Tsai, 2010). However, there has been inconsistent findings in relation to the construct validity of the instrument. For instance, Schmidt et al. (2009) and Lux, Bangert \& Whittier (2011) identified a seven and six-factor model respectively. Other researchers found domains that had been interpreted as a combined domain. For example, Chai, Koh \& Tsai (2010) found a four-factor model and Koh, Chai \& Tsai (2010) a five-factor model of TPACK. Therefore, the validity and reliability of TPACK used in other contexts are necessary to be examined in order to understand the relationships of TPACK. 


\section{LITERATURE REVIEW}

Mishra and Koehler (2006) have proposed a framework of Technological, Pedagogical Content Knowledge (TPACK) as shown in figure 1 that clarifies the need to develop and understand the technological, pedagogical and content knowledge to effectively integrate ICT in teaching. The TPACK model emphasizes how the connection of the three domains can enhance ICT use in teaching and learning. The combination of PK and CK forms Pedagogical Content Knowledge (PCK). This refers to teachers with the knowledge of delivering their subject effectively to help students to understand the subject clearly. CK and TK form Technological Content Knowledge (TCK) which enables usage of technology to promote teaching of the subject matter. TK and PK form Technological Pedagogical Knowledge (TPK) which helps teachers in choosing the appropriate and available technology tools to deliver the content, plan the lesson and manage the students. A combination of TK, CK and PK forms TPACK which enables teachers in delivering their subject content to the learners using the most appropriate available technology with suitable pedagogy (Mishra \& Koehler, 2006).

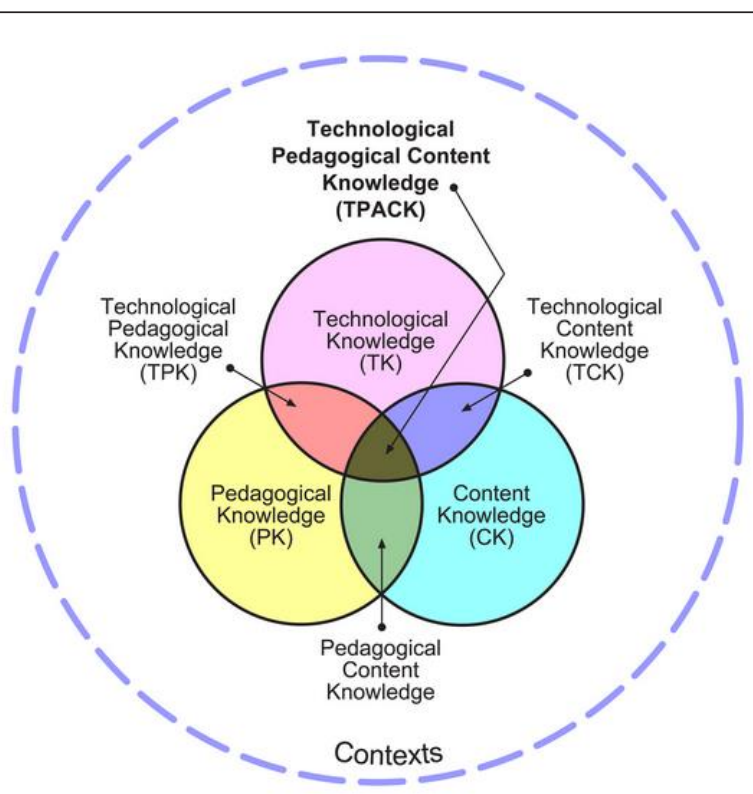

Figure 1. Technological pedagogical content knowledge (Retrieved from www.tpack.org). 
Studies on TPACK among in-service teachers (e.g.: Archambault \& Crippen, 2009; Grandgenette, 2008) and pre-service teachers (e.g.: Nordin, Morrow \& Davis, 2011; Koçoğlu, 2009; Neiss, 2005) has received high attention (Abbitt, 2011; Koehler, Shin, \& Mishra, 2011). However, it appears that, very little empirical study has been done in measuring TPACK particularly among pre-service teachers at the start of their field experience.

\section{Measuring TPACK}

Several studies have acknowledged the need to develop a more reliable and valid instrument in relation to measuring pre-service teachers' TPACK (Schmidt et. al., 2009; Koh, Chai \& Tsai, 2010). In line with this, several TPACK surveys that were developed and tested on teachers were reported to be of high internal reliability (Lux, Bangert \& Whittier, 2011; Schmidt et al. 2009; Archambault $\&$ Crippen, 2009). There were also studies which attempted to validate the TPACK instrument in different contexts (Jang \& Tsai, 2012; Sahin, 2011; Koh, Chai \& Tsai, 2010). Generally, there are different ways of measuring the TPACK of pre-service teachers. For example, by conducting self-reporting surveys (Schmidt et al., 2009; Archambault \& Crippen, 2009; Albion, Jamieson-Proctor, \& Finger, 2010) using pre- and post-surveys or course-specific surveys (Jang \& Tsai, 2012; Koehler \& Mishra, 2005; JamiesonProctor, Albion, Finger, Cavanagh, Fitzgerald, Bond \& Grimbeek, 2013), "technology integration assessment rubric" (Harris, Grandgenett, \& Hofer, 2010) and performance-based measurements like the individual task-based assessment (Koehler \& Mishra, 2005).

Koehler and Mishra (2005) began an effort to measure participants' learning in relation to TPACK. They developed a 14 items coursespecific questionnaire to measure 13 Masters students' TPACK development during their collaboration work with four faculty members in designing an online course. The findings indicated significant changes in participants' knowledge of technology application and TPACK, however, the items used were highly contextualized to the design of an online course. Building on the TPACK framework, a few studies were conducted to develop a survey measuring teachers' TPACK (Archambault \& Crippen, 2009; Schmidt, et. el., 2009; Sahin, 2011). For example, Archambault and Crippen (2009) developed a 24-items survey to assess 596 K-12 
online educators' TPACK from 25 states in the USA. The findings reported alpha reliability values ranged from .70 for Technological Content Knowledge to .89 for Technological Knowledge. There were significant correlations between all domains of TPACK. Archambault and Barnett (2010) revisited the study to establish construct validity of the instrument used. They reported that three separate factors (pedagogical content, technology-curricular content knowledge and technological knowledge) were extracted which explained 58.2\% of the amount of variance through factor analysis using varimax rotation. Structural Equation Model (SEM) analysis was conducted to identify the representation of TPACK constructs in a model (Jones, Adelson \& Archambault, 2011). There were discriminant validity issues when all seven constructs became the latent construct (Jones et al., 2011). Thus, CK and PK were proposed as indicators measuring PCK; TK, TCK and TPK as another set of indicators for TPACK and established the best goodness-of-fitness (GOF) with the data in the study. However, the items were specific to teaching online among in-service teachers and are not suitable for assessment of TPACK in broader educational and technological contexts such as teaching Mathematics or Computer Literacy subject. This is because teaching subject content using certain pedagogical approach and via technology must be studied in specific context, thus items used need to be adapted accordingly.

A few different sets of survey were developed in order to measure pre-service teachers' TPACK (e.g.: Schmidt et al., 2009; Sahin, 2011; Lux, Bangert \& Whittier, 2011; Jamieson-Proctor, et. al., 2013). Schmidt et al. (2009) developed a questionnaire and tested with 124 pre-service teachers majoring in elementary and early childhood education, focusing on four content areas (Mathematics, Literacy, Science and Social Studies) at a large Midwestern University. The development of survey went through a rigorous process and produced an instrument consisting of 46 items measuring the TPACK constructs. The alpha reliability values ranged from 0.75 to 0.92 for the various elements of the TPACK model, suggesting that the instrument was reliable. They found that all domains within the TPACK framework were significantly correlated with TPACK and the highest correlation was between Technological Pedagogical Knowledge and TPACK $(r=.71)$. However, due to the small sample size to conduct a factor analysis, the construct validity of the entire instrument was not established. 
In a more extended research by Lux, Bangert and Whittier (2011), they reported a six-factor model with TCK domain not emerging after the exploratory factor analysis. They developed and validated the Preservice Teacher Technological Pedagogical Content Knowledge (PT-TPACK) instrument with 120 pre-service teachers, the majority of whom had participated in field experience during their preparation programme. Beginning of 2011, the Teaching Teachers for the Future (TTF) TPACK survey was developed based on a theorised 4-factor structure, comprising scales to measure pre-service teachers' perceptions of confidence with and usefulness of ICT (Jamieson-Proctor, et. al., 2013). The TTF TPACK survey attempted to measure the changes in pre-service teachers' TPACK from their involvement in the TTF intervention conducted throughout 2011 at 39 Australian HEIs. The study was administered to all students (N $=12881$ ) in teacher preparation programs at participating HEIs in May - July 2011 and post-survey in October - November 2011 (N $=5809$ ). A set of 24 items was developed to measure pre-service teachers' use of ICT in their own teaching in two scales; TPK/TCK Confidence and TPK/TCK Usefulness. For TPACK construct, 20 items for two scales; TPACK Confidence and TPACK Usefulness were extended with four items describing how pre-service teachers might support future school students' use of ICT in the curriculum from the original TPACK Confidence Survey (TCS). In contrary to the current study and that of Schmidt et al. (2009) measure the perceptions of pre-service teachers in all seven TPACK domains, the TTF TPACK survey mainly measures two perceptions of preservice teachers; namely, ICT use for future teaching and support of students' learning.

Koh, Chai and Tsai (2010) revised Schmidt et al.'s (2009) survey to examine 1185 Postgraduate Diploma/Diploma in Education preservice teachers' technological pedagogical content knowledge (TPACK) in Singapore. The survey consisted of 29 items and reported a five-factor TPACK model. The findings established the construct validity for TK and CK items. The remaining items were grouped into and interpreted as knowledge of pedagogy (KP), knowledge of teaching with technology (KTT) and knowledge from critical reflection (KCR). 'Knowledge of Pedagogy' (KP) was identified as the combination of items for pedagogical knowledge and pedagogical content knowledge. TPK, TCK and TPACK items form the KTT factor. The fifth factor 'Knowledge from Critical 
Reflection' (KCR) consisted of items in relation to the teachers' reflections about technology integration. Similarly, Chai, Koh and Tsai (2011) performed an instrument validation with 214 Singaporean pre-service teachers. They inserted the phrase, "Without using technology ..." into PCK items in order to differentiate between PCK items, and TPK and TCK items. The instrument was highly contextualised to the ICT course offered in the programme which used Jonassen et al.'s (2008) meaningful learning framework that emphasized the specific activity. The findings reported a sevenfactor model of TPACK.

To summarize, studies which examined TPACK validation have shed light to its usefulness in identifying how pre-service teacher's perceived technology infusion in their teaching. The different findings for different contexts have triggered further need for validation studies.

Thus, the study seeks to establish the reliability and validity of TPACK and to evaluate the goodness of fit of the TPACK measurement model.

\section{METHODOLOGY}

Design of the study

This is a case study of the phenomenon of field experience used in the preparation of secondary school teachers at one public university in Malaysia. Case study examines "a contemporary phenomenon in depth and within its real-life context" (Yin, 2009) and assumes that examining the context related to the case is fundamental to the understanding of the case (Yin, 2012). The chosen case study can consist of a program, an entity, or an individual bounded by time and place (Stake, 2006) and data collection approach (Creswell, 2007). The selection of participants in this study was based on the maximum variation sampling to represent diverse cases in order to fully display multiple perspectives about the cases (Miles \& Huberman, 1994). Furthermore, the focus of the study was within the TPACK framework which consists of technological knowledge (TK), pedagogical knowledge (PK) and content knowledge (CK). 
Therefore, 'purposive sampling' (Simons, 2009) is used in the selection of participants with a total of 150 pre-service teachers who were undertaking field experience at schools.

\section{Survey instrument}

The TPACK surveys designed by Schmidt et al. (2009) were adapted to the context of study as the survey was used for pre-service teachers as well. The TPACK questionnaire was previously developed in the USA and has not been tested in a Malaysian education setting. Furthermore, some adaptations were made to the original TPACK survey specifically to $\mathrm{CK}$ to suit to the more general pre-service teacher's content knowledge (CK). For example, for CK domain, two items which measure the $\mathrm{CK}$ for the specific curriculum areas of Mathematics, Social Studies, Science, and Literacy were changed so that they measure the CK of the pre-service teachers' major and minor subjects during teacher training, i.e. ICT (CK1) and Economics (CK2). Therefore, the item "I have sufficient knowledge about social studies" was changed to "I have sufficient knowledge about my subject matter". The rest of the items for measuring TK, PK, TCK, PCK, TPK, and TPACK, came from either Schmidt et al. (2009) and/or Archambault and Crippen (2009) (see Table 1). The final adapted version of the TPACK survey consists of 37 items which were used to measure pre-service teachers' perceptions of TPACK with a five-point Likert-type scale: (1) strongly disagree;

(2) disagree; (3) neutral; (4) agree and (5) strongly agree.

Table 1

Items of TPACK Instrument

\begin{tabular}{llll}
\hline Subscales & $\begin{array}{c}\text { Number of } \\
\text { items }\end{array}$ & \multicolumn{1}{c}{ Sample items } & Source \\
\hline TK & 6 & $\begin{array}{l}\text { I know how to solve my own Schmidt et al. (2009) } \\
\text { technical problems. } \\
\text { I know about a lot of different } \\
\text { technologies. }\end{array}$ \\
PK & 5 & $\begin{array}{l}\text { I know how to assess student Schmidt et al. (2009) } \\
\text { performance in a classroom. } \\
\text { I know how to organize and } \\
\text { maintain classroom management. }\end{array}$ \\
\hline
\end{tabular}




\begin{tabular}{|c|c|c|c|}
\hline Subscales & $\begin{array}{c}\text { Number of } \\
\text { items }\end{array}$ & Sample items & Source \\
\hline$\overline{\mathrm{CK}}$ & $6(2+4)$ & $\begin{array}{l}\text { I have sufficient knowledge about } \\
\text { my subject matter. } \\
\text { I have various ways and strategies } \\
\text { of developing my understanding } \\
\text { of my subject matter. }\end{array}$ & $\begin{array}{l}\text { Archambault and } \\
\text { Crippen's (2009) } \\
\text { and Schmidt et al.'s } \\
(2009)\end{array}$ \\
\hline PCK & $5(1+4)$ & $\begin{array}{l}\text { I can select effective teaching } \\
\text { approaches to guide student } \\
\text { thinking and learning in my } \\
\text { subject matter. } \\
\text { I can produce lesson plans with a } \\
\text { good understanding of the topic } \\
\text { in my subject matter. }\end{array}$ & $\begin{array}{l}\text { Archambault and } \\
\text { Crippen's (2009) } \\
\text { and Schmidt et al.'s } \\
\text { (2009) }\end{array}$ \\
\hline TPK & 5 & $\begin{array}{l}\text { I can choose technologies that } \\
\text { enhance the teaching approaches } \\
\text { for a lesson. } \\
\text { I can choose technologies that } \\
\text { enhance students' learning of a } \\
\text { lesson. }\end{array}$ & Schmidt et al. (2009) \\
\hline TCK & $5(3+2)$ & $\begin{array}{l}\text { I know about technologies that } \\
\text { I can use for teaching specific } \\
\text { concepts in my subject matter. } \\
\text { I know how my subject matter can } \\
\text { be represented by the application } \\
\text { of technology. }\end{array}$ & $\begin{array}{l}\text { Archambault and } \\
\text { Crippen's (2009) } \\
\text { and Schmidt et al.'s } \\
(2009)\end{array}$ \\
\hline TPACK & 5 & $\begin{array}{l}\text { I can teach lessons that } \\
\text { appropriately combine my } \\
\text { subject matter, technologies, and } \\
\text { teaching approaches. } \\
\text { I can select technologies to use in } \\
\text { my classroom that enhance what } \\
\text { I teach, how I teach, and what } \\
\text { students learn. }\end{array}$ & Schmidt et al. (2009) \\
\hline
\end{tabular}

Note: $\mathrm{TK}=$ Technological Knowledge; $\mathrm{CK}=$ Content Knowledge; $\mathrm{PK}=$ Pedagogical Knowledge;

PCK = Pedagogical Content Knowledge; TCK = Technological Content Knowledge; TPK = Technological Pedagogical Knowledge; TPACK = Technological Pedagogical Content Knowledge

\section{Back-translation Process}

The adapted TPACK survey was translated from the source language (SLQ1) into the target language (Bahasa Malaysia version) by three people in the ICT in Education field who are bilingual. Translation is an iterative process which is essential whenever two or more languages are used by the community of the target population 
(Harkness, 2006). A combination of pretesting, decentering, back translation and committee approach as suggested by Brinslin (1980) was used to check for the appropriateness of the Bahasa Malaysia (Malay language) version of the TPACK survey among the preservice teachers in Malaysia. The Bahasa Malaysia version was pretested among five pre-service teachers. Based on their comments, the wordings of some items and the definition of each TPACK domain were slightly changed, removed and agreed upon to produce one set of items with appropriate wording in Bahasa Malaysia (decentering). The decentering method allows items to be translated appropriately into the targeted language without using the exact word-for-word translation from the original language. The Bahasa Malaysia version was then back translated into the source language (SLQ2) by another two people in the field who are bilingual to ensure accuracy (Brislin, 1970). In back-translation, a target language version is translated back into the source language version in order to verify translation of the research instrument (Brislin et al., 1970). The two sourcelanguage questionnaires (SLQ1 \& SLQ2) were compared and if the source language questionnaire (SLQ1) was equivalent to the retranslated back source language questionnaire (SLQ2), then the target language questionnaire was accepted (Harkness, \& SchouaGlusberg, 1998). The final translated questionnaire resulted in 37 items (details of items are shown in Table 1) with a five-point Likerttype scale: (1) strongly disagree; (2) disagree; (3) neutral; (4) agree and (5) strongly agree. The Bahasa Malaysia version of the TPACK survey was piloted with 30 pre-service teachers to re-examine the status of its internal consistency because of the adaptations and the different setting. Findings showed the reliability of the constructs ranged from .86 for Pedagogical Content Knowledge (PCK) to .92 for Technological Content Knowledge (TCK). Following that, the adapted TPACK survey was administered to the 150 pre-service teachers in a university in Malaysia during the teaching practice briefing session.

\section{Data Analysis}

Data screening was conducted involving checking of data accuracy input, addressing missing values, and determining normality and eliminating outliers. Following that, the analysis continued with the assessment of reliability and validity of the adapted instruments. Cronbach's alpha coefficients above 0.70 are generally acceptable 
(Hair et al., 2010). Confirmatory factor analysis (CFA) of the adapted TPACK survey was preceded by assessing the fit of the measurement model with the data in the study based on the a priori theoretical model. First, for model identification: 1) one path is fixed to 1 on each latent variable; 2 ) there were a minimum of three indicators per latent variable; and 3) the errors of the indicators were independent of each other. Then, all 37 items were analysed using AMOS 19.0, and its parameters were estimated via maximum likelihood procedure. The model was evaluated for goodness of fit using: 1) the Standardized Root Mean Square Residual (SRMR) with values of .08 or less are desired (Hu \& Bentler, 1999), 2) Root Mean Square Error of Approximation (RMSEA) values of .08 or less indicates adequate model fit (Brown \& Cudeck, 1993), 3) Comparative Fit Index (CFI) values greater than .90 support acceptable model fit (Bentler, 1990) and 4) the Tucker-Lewis index (TLI) with a value of 0.9 or more indicates a good fit (Hair, et al. 1998). It is recommended to use more than one fit index (from two different categories) to evaluate the model fit (Hu \& Bentler, 1998, 1999) as a ratio less than 5:1 may produce unstable results (Kline, 1998). The parameters estimated were greater than the absolute value of 1.96 significant at $\mathrm{p}<.05(\mathrm{t}>1.96, \mathrm{p}<.05)$, and the interpretability or strength of the parameter estimates (i.e., absence of Heywood cases and no negative variances) was also observed.

\section{FINDINGS}

Findings from survey analysis showed (see table 2) the reliability of the constructs ranged between .79 (TPK) and .88 (PK).

Table 2

Reliability of the TPACK Scales

\begin{tabular}{ll}
\hline \multicolumn{1}{c}{ Subscales } & Reliability $(\alpha)$ \\
\hline Technological Knowledge & .82 \\
Pedagogical Knowledge & .88 \\
Content Knowledge & .85 \\
Pedagogical Content Knowledge & .85 \\
\hline & (continued)
\end{tabular}




\begin{tabular}{ll}
\hline \multicolumn{1}{c}{ Subscales } & Reliability $(\alpha)$ \\
\hline Technological Pedagogical Knowledge & .79 \\
Technological Content Knowledge & .84 \\
Technological Pedagogical Content Knowledge & .84 \\
\hline
\end{tabular}

It was observed that the indicators were strongly related to their purported latent factors (ranging from $\beta=.52, \mathrm{t}=5.46$ to $\beta=.85$, $\mathrm{t}=6.87$, significant at $\mathrm{p}<.001)$ establishing the convergent validity of the measurement model. Figure 2 presented the factor loadings estimates for all seven TPACK constructs. Factor loadings of $>.50$ are recommended for the sample size of $<200$ (Hair et. al., 2010).

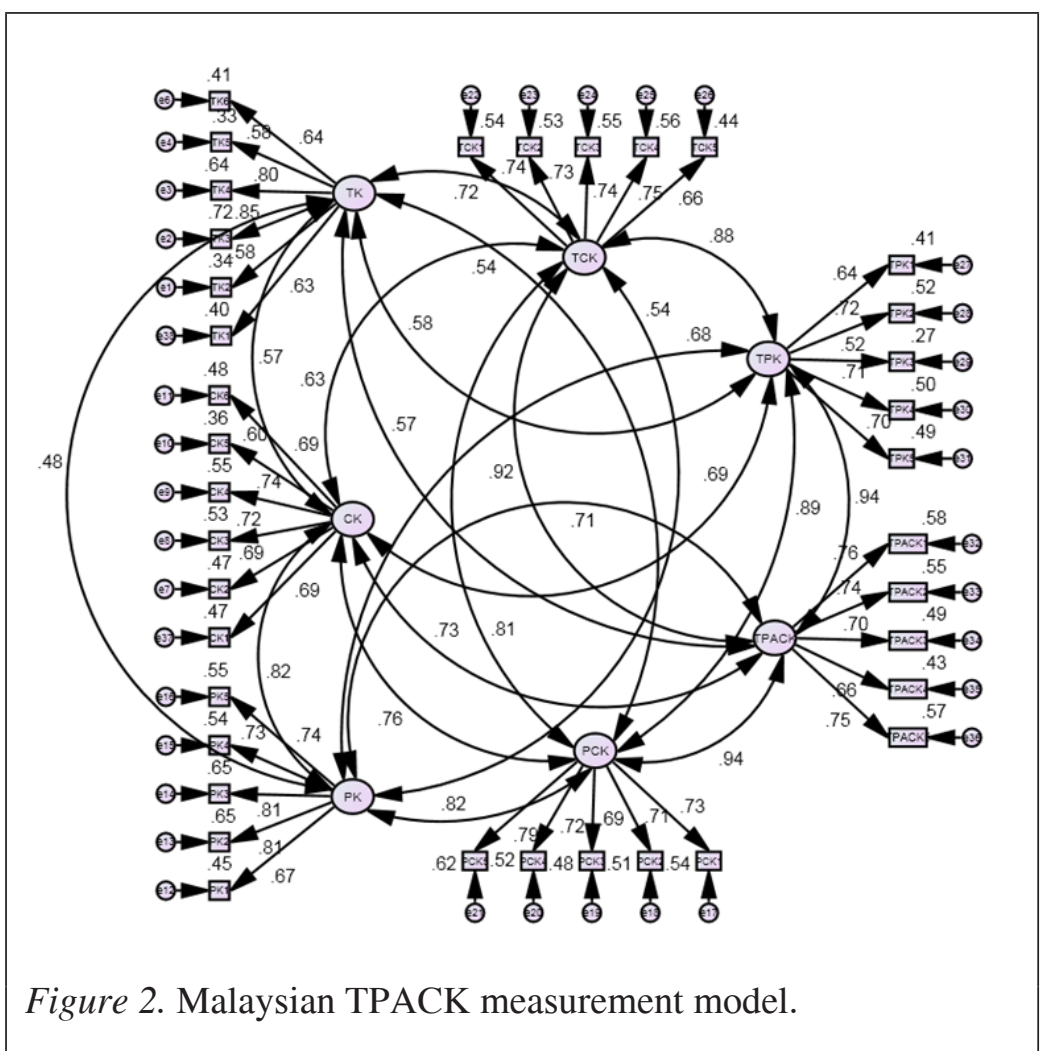

The results for the measurement model suggested that the sevenfactor model fits the data reasonably well, $\chi 2 / \mathrm{df}=1.672\left(\chi^{2}=\right.$ $1016.630, \mathrm{df}=608)$ and $\mathrm{p}=.000, \mathrm{TLI}=.85, \mathrm{CFI}=.86, \mathrm{RMSEA}=$ $.07(.06-.08)$ and SRMR $=.06$, fit indices suggesting an acceptablefitting model (Brown, 2006). According to Kim \& Bentler (2006), 
if a model has a "good" fit using more than one category, the model is an acceptable fit with the data under study. The chi-square statistic is recognized to be biased with small sample sizes (Jackson, 2003; MacCallum, Widaman, Preacher, \& Hong, 2001). Thus the ratio of the $\chi^{2}$ to degrees of freedom ( $\chi 2$ /df) less than 3 was suggested to indicate a good-fitting model (Chin, et al. 1995).

The interrelationships of TPACK factors

The correlations between the seven knowledge domains were all positive, ranging from the lowest value $\mathrm{r}=.48, \mathrm{t}=3.75, \mathrm{p}<.001$ between TK and PK, to the highest, $\mathrm{r}=.94, \mathrm{t}=5.50, \mathrm{p}<.001$ between TPK and TPACK and $\mathrm{r}=.94, \mathrm{t}=5.97, \mathrm{p}<.001$ between PCK and TPACK (see table 3 ). It was observed that the correlations between PCK and TPACK, TPK and TPACK; and TCK and TPACK were more than .90 , indicating that there is a high overlapping between these three domains. In other words, pre-service teachers could not differentiate the three domains, PCK, TPK and TCK from the domain of TPACK. However, to be consistent with a priori theoretical model, we decided to keep the four constructs as distinct factors instead of collapsing the two dimensions into a single factor. The correlations between the other latent variables was less than .90 (Hair et. al., 2010), thus establishing the discriminant validity.

Table 3

Correlations between TPACK Subscales

\begin{tabular}{lccccccc}
\hline $\begin{array}{c}\text { TPACK } \\
\text { Subscales }\end{array}$ & TK & CK & PK & PCK & TCK & TPK & TPACK \\
\hline TK & 1.00 & $.59 *$ & $.48^{*}$ & $.54^{*}$ & $.72 *$ & $.59^{*}$ & $.57^{*}$ \\
CK & & 1.00 & $.82^{*}$ & $.76^{*}$ & $.64^{*}$ & $.69 *$ & $.73^{*}$ \\
PK & & & 1.00 & $.82^{*}$ & $.54^{*}$ & $.68^{*}$ & $.71^{*}$ \\
PCK & & & & 1.00 & $.82^{*}$ & $.89 *$ & $.94^{*}$ \\
TCK & & & & & 1.00 & $.88^{*}$ & $.92^{*}$ \\
TPK & & & & & & 1.00 & $.94^{*}$ \\
TPACK & & & & & & & 1.00 \\
\hline
\end{tabular}

Note: *. Correlation is significant at the 0.001 level (2-tailed); $\mathrm{TK}=$ Technological Knowledge;

$\mathrm{CK}=$ Content Knowledge; $\mathrm{PK}=$ Pedagogical Knowledge; $\mathrm{PCK}=$ Pedagogical Content Knowledge; TCK = Technological Content Knowledge; TPK = Technological Pedagogical Knowledge; TPACK = Technological Pedagogical Content Knowledge 


\section{DISCUSSION}

The Technological,PedagogicalContentKnowledge(TPACK) model clarifies the need to develop technological knowledge, pedagogical knowledge and content knowledge and suggests that the importance of combining three different components to enhance teaching with technology (Mishra \& Koehler, 2006). Technological pedagogical content knowledge (TPACK) can be defined as understanding the connection and interaction between the technological knowledge (technology tools: computer), content knowledge (subject to be taught) and pedagogical knowledge (strategies, practices, approach, and method of teaching and learning). As proposed by Mishra and Koehler (2006), teachers are best prepared with the understanding of this knowledge. It was found in this study that the seven-factor model of TPACK was acceptably fit with the data collected from the secondary school pre-service teachers in Malaysia. The convergent validity was established with items loaded highly on the expected factors. The study provided another support for the robustness of this instrument in terms of the reliability, construct validity and applicability of its adapted and translated version in a different context. In other words, the adapted and translated TPACK survey was found to be a valuable self-report instrument for measuring pre-service teachers' TPACK knowledge. Furthermore, this study contributed to increased reliability of TPACK instrumentation as well as gathering a data set in Malaysia for the first time.

The structure of the TPACK model had been found to be inconsistent in previous studies. For example, some studies identified all domains of the TPACK model: Schmidt et al. (2009) identified a seven-factor model and Shinas, Yilmaz-Ozden, Mouza, KarchmerKlein \& Glutting (2013) reported an eight-factor model; while others found aspects had been combined: Chai et al. (2010) found a four-factor model and Koh, Chai \& Tsai (2010) identified a fivefactor model of TPACK. Specific teaching about TPACK in teacher education program was identified as likely to be linked with more understanding of TPACK. For instance, students at a Midwestern university in USA had been introduced to TPACK in a 3-credit course that introduced ICT in learning and teaching. Following the course, a study was conducted to perform a validation of TPACK model which identified a seven-factor model (Schmidt et al., 2009), and a similar course in a mid-Atlantic university in the United States 
(Shinas et al., 2013). TPACK was also emphasized in a 12-week compulsory ICT integration course entitled "ICT for Meaningful Learning" in Singapore that reported eight factors of TPACK (CK factor was separated into two specific CK factors) (Chai, Koh \& Tsai, 2011).

Where students had not been taught about TPACK the model had less factors; as in this Malaysian case study. In this study, the Malaysian pre-service teachers did not clearly distinguish their PCK, TPK, TCK and TPACK, suggesting that these pre-service teachers could not differentiate between the technology-related domains and the PCK. Koh, Chai and Tsai (2010) administered their TPACK survey at the beginning of the programme to Singaporean pre-service teachers who interpreted the items in TCK, TPK and TPACK as being in a similar domain and interpreted the PK and PCK items as one factor. This research therefore recommends, along with Koh et al. (2010) that the TPACK instrument include the phrase "without using technology..." at the beginning of all PCK items in order to help pre-service teachers differentiate between PCK and the technology-related domains. Furthermore, both recommend using subject-based TPACK items in TPACK surveys to help pre-service teachers distinguish the different TPACK factors, especially in the case of secondary subject specialists as compared to primary or early childhood education generalists where content is more integrated.

Lux, Bangert and Whittier (2011) in their study identified a six-factor model. Although they did not state clearly whether the pre-service teachers had been introduced to TPACK before the distribution of the survey, it is believed that the six-factor model emerged not only after the method course but also during field experience. Furthermore, the absence of TCK domain in their study was believed to be because the pre-service teachers could not separate the selection of their PK when choosing the technology to be used in teaching (Lux, Bangert $\&$ Whittier, 2011). Additionally, to understand and develop TPACK, one needs to concentrate on choosing the appropriate technology within specific topics and pedagogical activities as TPACK is very context specific (Mishra \& Koehler, 2006). Therefore, variations occurred when teachers attempted to apply TPACK within their own context as the model is contextualised to specific topics and activities (Cox \& Graham, 2009). 


\section{FUTURE DIRECTIONS FOR RESEARCH}

This study was designed as a case study situated within particular context in Malaysia, therefore limiting the generalizability of the findings to other contexts. Despite the limitations of the transferability of the findings the case study methodology utilized in this study provided an opportunity to conduct the research within a naturalistic environment. This approach allowed the researcher to conduct an in-depth investigation of the phenomenon as well as to contribute to the research field as there is a lack of studies which have investigated pre-service teachers' TPACK in Malaysian secondary schools. Furthermore a case study allows theoretical generalization which enables the researcher to take a perspective which suits their context (Yin, 2009).

Further studies are therefore recommended in order to provide more insights to deepen understanding of how to effectively integrate ICT in teaching, including field experience. As exemplified in the current study, the TPACK survey, with some adaptations, was proven a reliable and valid instrument to be used in the setting of the current research. Despite evidence of good psychometric properties of the instruments used in this study, validity of the instruments in similar settings needs to be further enhanced through replication of the study. Further research into the practice of a larger sample of Malaysian pre-service teachers may reveal further variations of practice as well as enable greater confirmation and generalisation of these findings. Furthermore, the sample involved in this study was secondary school pre-service teachers. Thus, other areas that are recommended for further research include primary school preservice teachers and in-service teachers.

Additionally, greater understanding of TPACK may be required for pre-service teachers before adequate gains in using ICT in teaching can be achieved. Thus, the promotion of TPACK in Initial Teacher Education programmes can expose pre-service teachers to the complexity of knowledge interaction, to further their knowledge and skills through practice while teaching during field experience. This approach can help pre-service teachers develop the knowledge and skills required to effectively integrate ICT in teaching. However, in realising the potential of integrating ICT in teaching, especially during pre-service teachers' field experience, the schools have to be 
well equipped with ICT facilities and support. It is recommended that this knowledge should be integrated in the Initial Teacher Education curriculum with more attention to improving access to ICT in Initial Teacher Education and the schools. It is also suggested that the TTF measure should be contrusted with those applied in this research study. The TTF TPACK survey measures two perceptions of preservice teachers (1) ICT use for future teaching and (2) support of students' learning. In contrast, the current study and that of Schmidt et al. measures the perceptions of pre-service teachers in all seven TPACK domains. It appears that the selection of two of the seven domains and the addition of a view on teacher's use and students' learning may improve the measurement of TPACK.

\section{ACKNOWLEDGEMENTS}

The authors wish to acknowledge the support from pre-service teachers who participated in the study; the University of Canterbury, New Zealand for the unconditional support during the period of study and the Ministry of Education, Malaysia, for the finding.

\section{REFERENCES}

Abbitt, J. T. (2011). Measuring technological pedagogical content knowledge in preservice teacher education: A review of current methods and instruments. Journal of Research on Technology in Education, 43, 281-300.

Albion, P. R., Jamieson-Proctor, R. \& Finger, G. (2010). Auditing the TPACK confidence of Australian pre-service teachers: The TPACK confidence survey (TCS). In 21st International Conference of the Society for Information Technology \& Teacher Education (SITE 2010), 29 Mar-2 Apr 2010, San Diego, CA, United States.

Al-Ruz, J., \& Khasawneh, S. (2011). Jordanian pre-service teachers' and technology integration: A human resource development approach. Journal of Educational Technology \& Society, 14(4), 77-87. Retrieved from: http://ehis.ebscohost.com

Al-Weher, M., \& Abu-Jaber, M. (2007). The effectiveness of teacher preparation programs in Jordan: A case study. 
In T. Townsend, \& R. Bates (Eds.), Handbook of teacher education: Globalization, standards and professionalism in times of change ( $\mathrm{pp}$ 3-22). Netherlands: Springer.

Alayyar, G., Fisser, P., \& Voogt, J. (2012). Developing technological pedagogical content knowledge in pre-service science teachers: Support from blended learning. Australasian Journal of Educational Technology, 28(8), 1298-1316.

Archambault, L., \& Crippen, K. (2009). Examining TPACK among K-12 online distance educators in the United States. Contemporary Issues in Technology and Teacher Education, 9(1), 71-88.

Archambault, L., \& Barnett, J. (2010). Revisiting technological pedagogical content knowledge: Exploring the TPACK Framework. Computers \& Education, 55(4), 1656-1662.

Baran, E., Chuang, H.-H., \& Thompson, A. (2011). TPACK: An emerging research and development tool for teacher educators. TOJET: The Turkish Online Journal of Educational Technology, 10(4), 370-377.

Bentler, P. M. (1990). Comparative fit indexes in structural models. Psychological Bulletin, 107(2), 238-246.

Brislin, R.W. (1970). Back-translation for cross-cultural research. Journal of Cross-cultural Psychology, 1(3), 185-216.

Brislin R.W. (1980). Translation and content analysis of oral and written material. In H. C. Trandis, \& J. W. Berry (Eds.), Handbook of cross-cultural psychology: Methodology Vol. 2 (pp. 389-444). Boston.

Brown, M. W., \& Cudeck, R. (1993). Alternative ways of assessing model fit. In K. A. Bollen, \& J. S. Long (Eds.), Testing structural equation models (pp. 136-162). Newbury Park, CA: Sage.

Brown, T. A. (2006). Confirmatory factor analysis for applied research. New York, NY: The Guilford Press.

Chai, C. S., Koh, J. H. L., \& Tsai, C. C. (2010). Facilitating preservice teachers' development of technological, pedagogical, and content knowledge (TPACK). Educational Technology and Society, 13(4), 63-73.

Chai, C. S., Koh, J. H. L., Tsai, C., \& Tan, L. L. W. (2011). Modeling primary school pre-service teachers' Technological Pedagogical Content Knowledge (TPACK) for meaningful learning with information and communication technology (ICT). Computers \& Education, 57, 1184-1193. 
Chan, F.-M. (2002). ICT in Malaysian schools: Policy and strategies. Retrieved from http://unpan1.un.org/intradoc/groups/public/ documents/apcity/unpan011288.pdf

Chin, W. W., \& Todd, P. A. (1995). On the use, usefulness and ease of structural equation modelling in mis research: A note of caution. MIS Quarterly, 19(2), 237-247.

Choy, D., Wong, A., \& Gao, P. (2008). Singapore's preservice teachers' perspectives in integrating information and communication technology (ICT) during practicum. Paper presented at the AARE Conference.

Creswell, J. (2007). Qualitative inquiry \& research design: Choosing among five approaches (2nd ed.). Thousand Oaks: Sage Publications

Cohen, J. (1988). Statistical power analysis for the behavioral sciences (2nd ed.). Mahwah, NJ: Lawrence Erlbaum Associates.

Cox, S., \& Graham, C. R. (2009). Diagramming TPACK in practice: Using and elaborated model of the TPACK framework to analyse and depict teacher knowledge. TechTrends, 53(5), $60-69$.

Davis, N. E. (2010). Technology and preservice teacher education. In M.G. Barry, B. Eva \& P. Penelope (Eds.), International Encyclopedia of Education (3rd edition). Oxford: Elsevier.

Frost, \& Sullivan Report. (2010). Policy on ICT in education Malaysia. Retrieved from http://www.mscmalaysia.my/sites

Grandgenett, N. F. (2008). Perhaps a matter of imagination TPCK in mathematics education. In AACE (Ed.), The handbook of Technological Pedagogical Content Knowledge (TPCK) for educators. New York: Routledge.

Hair, J. F., Jr., Anderson, R. E., Tatham, R. L., \& Black, W. C. (1998). Multivariate data analysis (5th ed). Upper Saddle River, NJ: Prentice Hall.

Hair, J., Black, B. Babin, B., Anderson, R., \& Tatham, R. (2006). Multivariate data analysis (6th ed.). Upper Saddle River, NJ: Prentice-Hall.

Hair, J. F., Black, W. C., Babin, B. J., \& Anderson, R. E. (2010). Multivariate data analysis (7th ed.). Upper Saddle River, NJ: Prentice Hall.

Harris, J., Grandgenett, N. \& Hofer, M. (2010). Testing a TPACKbased technology integration assessment rubric. In D. Gibson, 
\& B. Dodge. (Eds.), Proceedings of Society for Information Technology \& Teacher Education International Conference 2010 (pp. 3833-3840). Chesapeake, VA: AACE.

Harkness, J. A. (2006). Round 3 ESS translation guidelines. ESS document, April.

Harkness, J. A. \& Schoua-Glusberg, A. (1998). Questionnaires in translation. In J. A. Harkness (Ed.), Cross-cultural survey equivalence (pp. 87-128). ZUMA-Nachrichten Spezial, No. 3 (Mannheim: Zentrum fur Umfragen, Methoden und Analysen).

Harris, D. N., \& Sass, T. R. (2011). Teacher training, teacher quality and student achievement. Journal of Public Economics, 95, 798-812.

Hu, L. T., \& Bentler, P. M. (1998). Fit indices in covariance structure modelling: sensitivity to underparameterized model misspecification. Psychological Methods, 3(4), 424-453.

Hu, L. T., \& Bentler, P. M. (1999). Cutoff criteria for fit indexes in covariance structure analysis: conventional criteris versus new alternatives. Structural Equation Modeling, 6(1), 1-55.

Inan, F. A. \& Lowther, D. L. (2009). Factors affecting technology integration in K-12 classroom: a path model. Educational Technology Research and Development. doi:10.1007/s11423009-9132-y.

Jackson, D. L., (2003). Revisiting sample size and number of parameter estimates: Some support for the N:q hypothesis. Structural Equation Modelling, 10, 128-141.

Jamieson-Proctor, R., Albion, P., Finger, G., Cavanagh, R., Fitzgerald, R., Bond, T., \& Grimbeek, P. (2013). Development of the TTF TPACK Survey Instrument. Australian Educational Computing, 27(3), 26-35.

Jang, S., \& Tsai, M.-F. (2012). Exploring the TPACK of Taiwanese elementary mathematics and science teachers with respect to use of interactive whiteboards. Computers \& Education, 59(2), 327-338.

Jonassen, D., Howland, J., Marra, R., \& Crismond, D. (2008). Meaningful learning with technology (3rd ed.). Upper Saddle River, NJ: Pearson.

Jones, B., Adelson, J., \& Archambault, L. (2011). Using SEM to move from theory to practice with the TPACK Framework. In Proceedings of Society for Information Technology \& Teacher Education International Conference 2011 (pp. 25182525). Chesapeake, VA: AACE. 
Kay, R. H. (2006). Evaluating strategies used to incorporate technology into pre-service education: A review of the literature. Journal of Research on Technology in Education, 38(4), 383-408.

Kim, K. H., \& Bentler, P. M. (2006). Data Modeling: Structural equation modeling. In Judith, G. L., Gregory, L, \& Patricia, B. E. (Eds.), Handbook of complementary methods in education research. New York: Routledge Taylor \& Francis Group.

Kirschner, P., \& Davis, N. (2003) Pedagogic benchmarks for information and communications technology in teacher education. Technology, Pedagogy and Education, 12(1), 125-147.

Kline, R. B. (1998). Principles and practice of structured equation modeling. New York: Guildwood.

Koçoğlu, Z. (2009). Exploring the technological pedagogical content knowledge of pre-service teachers in language education. Procedia - Social and Behavioral Sciences, 1(1), 2734-2737.

Koehler, M. J., \& Mishra, P. (2005). What happens when teachers design educational technology? The development of technological pedagogical content knowledge. Journal of Educational Computing Research, 32(2), 131-152.

Koehler, M. J., Shin, T. S., \& Mishra, P. (2011). How do we measure TPACK? Let me count the ways. In R. N. Ronau, C. R. Rakes, \& M. L. Niess (Eds.), Educational technology, teacher knowledge, and classroom impact: A research handbook on frameworks and approaches (pp. 16-31). Hershey, PA: IGI Global.

Koh, J. H. L., Chai, C. S., \& Tsai, C. C. (2010). Examining the technology pedagogical content knowledge of Singapore pre-service teachers with a large-scale survey. Journal of Computer Assisted Learning, 26(6), 563-573.

Law, N. (2010). Teacher Skills and Knowledge for Technology Integration. In Peterson P., Baker E. \& McGaw B., (Eds.), International Encyclopedia of Education, 8, 217-221. Oxford: Elsevier.

Letchumanan, K., \& Hoon, T. B. (2012). Using computer games to improve secondary school students' vocabulary acquisition in English. Pertanika Journal of Social Science \& Humanities, 20 (4), 1005-1018.

Linn, M. C., Clark, D., \& Slotta, J. D. (2003). WISE design for knowledge integration. Science Education, 87, 517-538. 
Lux, Bangert \& Whittier. (2011). The development of an instrument to assess preservice teacher's technological pedagogical content knowledge. Journal of Educational Computing Research, 45(4), 415-431.

MacCallum, R. C., Widaman, K. F., Preacher, K. J., \& Hong S. (2001). Sample size in factor analysis: The role of model error. Multivariate Behavioral Research, 36(4), 611-637.

Miles, M. B., \& Huberman, A. M. (1994). Qualitative data analysis: An expanded sourcebook (2nd ed). Newbury Park, CA: Sage. Ministry of Education Malaysia. (1998). A guide towards smart school. Curriculum Development Centre.

Ministry of Education Malaysia (2012). 1BestariNet. Retrieved from http://1bestarinet.net/

Mishra, P., \& Koehler, M. J. (2006). Technological pedagogical content knowledge: A framework for integrating technology in teachers' knowledge. Teachers College Record, 108(6), $1017-1054$.

Niess, M. L. (2005). Preparing teachers to teach science and mathematics with technology: Developing a technology pedagogical content knowledge. Teaching and Teacher Education, 21(5), 509-523.

Nordin, H., Morrow, D., \& Davis, N. (2011). Pre-service teachers' experience with ICT integration in secondary schools: A case study of one New Zealand context. In M. Koehler, \& P. Mishra (Eds.), Proceedings of Society for Information Technology \& Teacher Education International Conference 2011 (pp. 3915-3920). Chesapeake, VA: AACE.

Sahin, I. (2011). Development of survey of Technological Pedagogical and Content Knowledge (TPACK). Turkish Online Journal of Educational Technology - TOJET, 10(1), 97-105.

Schmidt, D. A., Baran, E., Thompson, A. D., Mishra, P., Koehler, M. J., \& Shin, T. S. (2009-2010). Technological Pedagogical Content Knowledge (TPACK): The development and validation of an assessment instrument for pre-service Teachers. Journal of Research on Technology in Education, 42(2), 123-149.

Shinas, V. H., Yilmaz-Ozden, S., Mouza, C., Karchmer-Klein, R. \& Glutting, J. J. (2013). Examining domains of technological pedagogical content knowledge using factor analysis. Journal of Research on Technology in Education, 45(4), 339-360

Simons, H. (2009). Case study research in practice. London: Sage. 
Stake, R. E. (2006). Multiple case study analysis. New York: Guilford Press.

Townsend, T., \& Bates, R. (2007). Teacher education in a new millennium: Pressures and possibilities. In T. Townsend \& R. Bates, (Eds.), Handbook of teacher education: Globalization, standards and professionalism in times of change pp. 3-22. Netherlands: Springer.

Timperley, H. S. (2012). Learning to practise in initial teacher education. Draft Paper for Discussion and Consultation. Auckland: The University of Auckland, 1-47.

UNESCO Bangkok. (2013). Case studies on integrating ICT into teacher education curriculum in Asia. Bangkok: UNESCO Bangkok, $94 \mathrm{p}$.

Willis, J. W., \& Mehlinger, H. D. (1996). Information technology and teacher education. In J. Sikula, T. Buttery, \& E. Guyton. (Eds.), Handbook of research on teacher education (2nd ed.), (pp. 978-1029). New York: Simon and Schuster.

Yin, R. K. (2009). Case study research: Design and methods (4th ed. Vol. 5). United States of America: Sage.

Young, S.-S.-C., \& Wang, Y.-H. (2014). The game embedded CALL system to facilitate English vocabulary acquisition and pronunciation. Educational Technology \& Society, 17 (3), 239-251.

Zaibon, S. B., \& Shiratuddin, N. (2010). Mobile Game-Based Learning (mGBL): Application development and heuristics evaluation strategy. Malaysian Journal of Learning Instruction, 7, 37-73. 